\title{
Analysis of the type of Achnanthes exigua Grunow (Bacillariophyta) with the description of a new Antarctic diatom species
}

\author{
Jonathan C. TAYLOR ${ }^{1,2,3}$, Christine COCQUYT ${ }^{3}$, Balasubramanian KARTHICK ${ }^{1,4} \&$ Bart \\ VAN DE VIJVER ${ }^{3,5^{*}}$
}

\author{
${ }^{I}$ School of Biological Sciences, North-West University, Potchefstroom, South Africa \\ ${ }^{2}$ South African Institute for Aquatic Biodiversity, Grahamstown, South Africa \\ ${ }^{3}$ Botanic Garden Meise, Department of Bryophyta \& Thallophyta, Domein van Bouchout, B-1860 Meise, Bel- \\ gium; *Corresponding author e-mail:vandevijver@br.fgov.be) \\ ${ }^{4}$ Gubbi Labs, \# 2- 182, $2^{\text {nd }}$ Cross, Extension, Gubbi- 572 216, Karnataka, India \\ ${ }^{5}$ University of Antwerp, Department of Biology, ECOBE, Universiteitsplein 1, B-2610 Wilrijk, Belgium
}

\begin{abstract}
A study was made of the type material of Achnanthidium exiguum (GRUNOw) CZARNECKI. This often encountered and apparently ubiquitous species was originally described as Stauroneis exilis by KüTZING from the island of Trinidad and later re-named as Achnanthes exigua by Grunow. The type material for this taxon (KÜTZING sample 397), housed in the VAN HEURCK collection at the National Botanic Garden of Belgium, Meise was investigated and the ultrastructure of this taxon was documented using both LM and SEM observations. A new Antarctic taxon, formerly identified as A. exigua, was described as a new species, Achnanthidium australexiguum sp. nov. The position of both taxa within the genus Achnanthidium is briefly discussed.
\end{abstract}

Key words: Achnanthidium australexiguum, A. exiguum, Maritime Antarctic Region, morphology, type material

\section{INTRODUCTION}

Widely distributed diatom taxa such as Planothidium lanceolatum (BréBISSON) LANGE-Bertalot, Stauroneis anceps EHRENBERG or Achnanthidium minutissimum (KÜTZING) CZARNECKI were often described by the early diatom taxonomists who developed a species concept based on light microscopy analysis, illustrating this concept by line drawings (e.g. EhrenBerg 1843; VAN Heurck 1880-1885; Krasske 1939; Hustedt 1937; Cleve-Euler 1953). The result is that we usually have a drawing that is essentially the author's interpretation of a species concept that later became coupled in Europe and North-America with a modern taxonomic concept based on light and electron photomicrographs. However, since careful examination of the type or the original material of diatom taxa is usually lacking even when this material originated from another continent, this has often led to a too broad interpretation of the original species concepts and subsequently to forcefitting similar populations from other continents into these old names (TYLER 1996) essentially creating species complexes or what is referred to in German as ' $\mathrm{Si}$ ppen'. Moreover, it becomes quite problematic when species closely related to the original taxon need to be described as new but no clear concept of the type is available. As these common taxa are often important in biomonitoring and (paleo-)ecological studies, it is very difficult to assign exact ecological preferences to them making them less useful in environmental studies. Although, in the last couple of years, more and more of these common taxa such as Nitzschia inconspicua Grunow, the Stauroneis anceps-complex, Nitzschia palea (Kützing) W. Sмiтн, Planothidium lanceolatum and the Achnanthidium minutissimum-complex have been restudied based on a thorough and detailed examination of their type material using both LM and SEM observations (REICHARDT 1995; TROBAJO et al. 2009, 2013; VAn De ViJver et al. 2013; Wetzel et al. 2013), many of these taxa still await better characterization and delimitation. One of these taxa is Achnanthidium exiguum (GRUNow) CZARNECKI, reported from almost all continents including the Antarctic Region (Schoeman \& Archibald 1976; Lange-Bertalot \& Krammer 1989, Kellogg \& Kellogg 2002; Metzeltin et al. 2005; Alakananda et al. 2013).

Achnanthidium exiguum was originally described from Trinidad and Tobago by KüTZING in 1844 as Stauroneis exilis KüTZING and illustrated by a rather minute line diagram (Fig. 1). KüTZING's original sample register kept at the National Botanic Garden of Belgium, states with reference to this species: "397 Stauroneis exilis, stagnant water near a watermill Tacarigua XVI No 42". The original Kützing material of $S$. exilis (present in the British Museum and the Grunow collection in Vienna) was studied and illustrated by Schoeman \& 
Archibald (1976) by means of light microscopy (LM, Figs 15-22b) and transmission electron microscopy (TEM, Figs 41-45) observations. The latter authors however were rather suspicious about the origin of the material that was used for TEM since the samples were labeled Achnanthes exigua (and not S. exilis). However, the sample register of the KüTZING collection was annotated by GRUNOw (signed 'Gr') with the following "Achnanthes exigua Gr Nitz palea var. debilis (Kz)" indicating that the KÜTZING sample 397 indeed contained the type material for this species. Based on observations of the KüTZING material, GRUNOw (in Cleve \& GRUNOW 1880) renamed this taxon as Achnanthes exigua GRUNOw. As KützING had already described in 1833 another species under the name Achnanthes exilis, it was impossible for GRUNOw to use the species epithet 'exilis' for the transferred taxon.

During a survey of the freshwater diatom flora in the Maritime Antarctic Region, several populations of a taxon identified as $A$. exiguum were found. A literature search based on KellogG \& Kellogg (2002) resulted in a list of almost 20 Antarctic references for this species. Almost all these records originate from

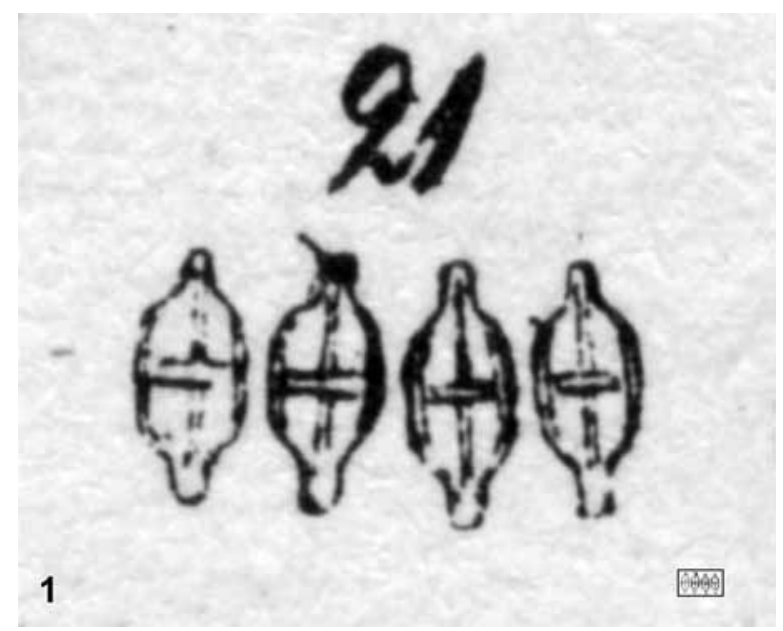

Fig. 1. Stauroneis exilis KüTzING. Original line drawing from KüTZING (1944, plate 30, fig. 21). Inset shows the approximate scale of the original illustration. the South Shetland Islands (Maritime Antarctic Region), making it likely that they all represent the same species. Comparing the ultrastructure of some of the Antarctic populations with the type material, revealed several significant morphological differences making conspecificity highly unlikely.

The present paper discusses the morphology of the type of Achnanthidium exiguum (Stauroneis exilis) using both LM and scanning electron microscopy (SEM) observations of "sample 397" from the KüTZING collection housed at the National Botanic Garden of Belgium. Additionally, the Achnanthidium populations formerly identified as A. exiguum from the Maritime Antarctic Region are described as $A$. australexiguum VAN DE VIJVER sp. nov.

\section{Material And Methods}

A duplicate of KüTZING's sample 397 was found in the KüTZING Collection deposited in the VAN Heurck Collection, currently housed at the National Botanic Garden (Meise) of Belgium. A subsample of this material was prepared for LM and SEM analysis.

During the past 5 years, sediment samples from a large number of lakes were collected during several field campaigns on Livingston Island (South Shetland Islands) and James Ross Island. Table 1 lists all samples with populations formerly identified as $A$. exiguum that have been analysed during this study. Kopaloví \& VAN DE ViJver (2013) and Kopaloví et al. (2013) discuss in detail the physic-chemical characteristics of the studied waterbodies.

Diatom samples for LM observation were prepared following the method described in VAN DER WERFF (1955). Subsamples of the original material were oxidized using $37 \%$ $\mathrm{H}_{2} \mathrm{O}_{2}$ and heated to $80{ }^{\circ} \mathrm{C}$ for approximately $1 \mathrm{~h}$. The reaction was further completed by the addition of $\mathrm{KMnO}_{4}$. Following digestion and centrifugation (three times 10 minutes at $3700 \times \mathrm{g}$ ), the material free of organic matter was diluted with distilled water for sample mounting to avoid excessive concentrations of diatom valves and frustules on the slides. A subsample from the organic-free material was mounted in Naphrax ${ }^{\circledR}$ for diatom community studies. The slides were analyzed using an Olympus BX53 microscope, equipped with Differential Interference Contrast (Nomarski), and the Colorview I Soft Imaging System. For scanning electron

Table 1. List of samples used in this study.

\begin{tabular}{lllll}
\hline Sample ID & Geographic locality & Source & Habitat & sample type \\
\hline LIV-BY051 & Livingston Island & KopALOVÁ \& VAN DE VIJVER (2013) & Lake & algal mat \\
JRI2008-D3 & James Ross Island & KopALOVÁ et al. (2013) & Lake & epipelon \\
JRI2008-D10 & James Ross Island & KopALOVÁ et al. (2013) & Lake & epipelon \\
JRI2008-D11 & James Ross Island & KopALOVÁ et al. (2013) & Lake & epilithon \\
JRI2008-D29 & James Ross Island & KopALOVÁ et al. (2013) & Lake & epipelon \\
JRI2008-D37 & James Ross Island & KopALOVÁ et al. (2013) & Lake & epilithon \\
\hline
\end{tabular}



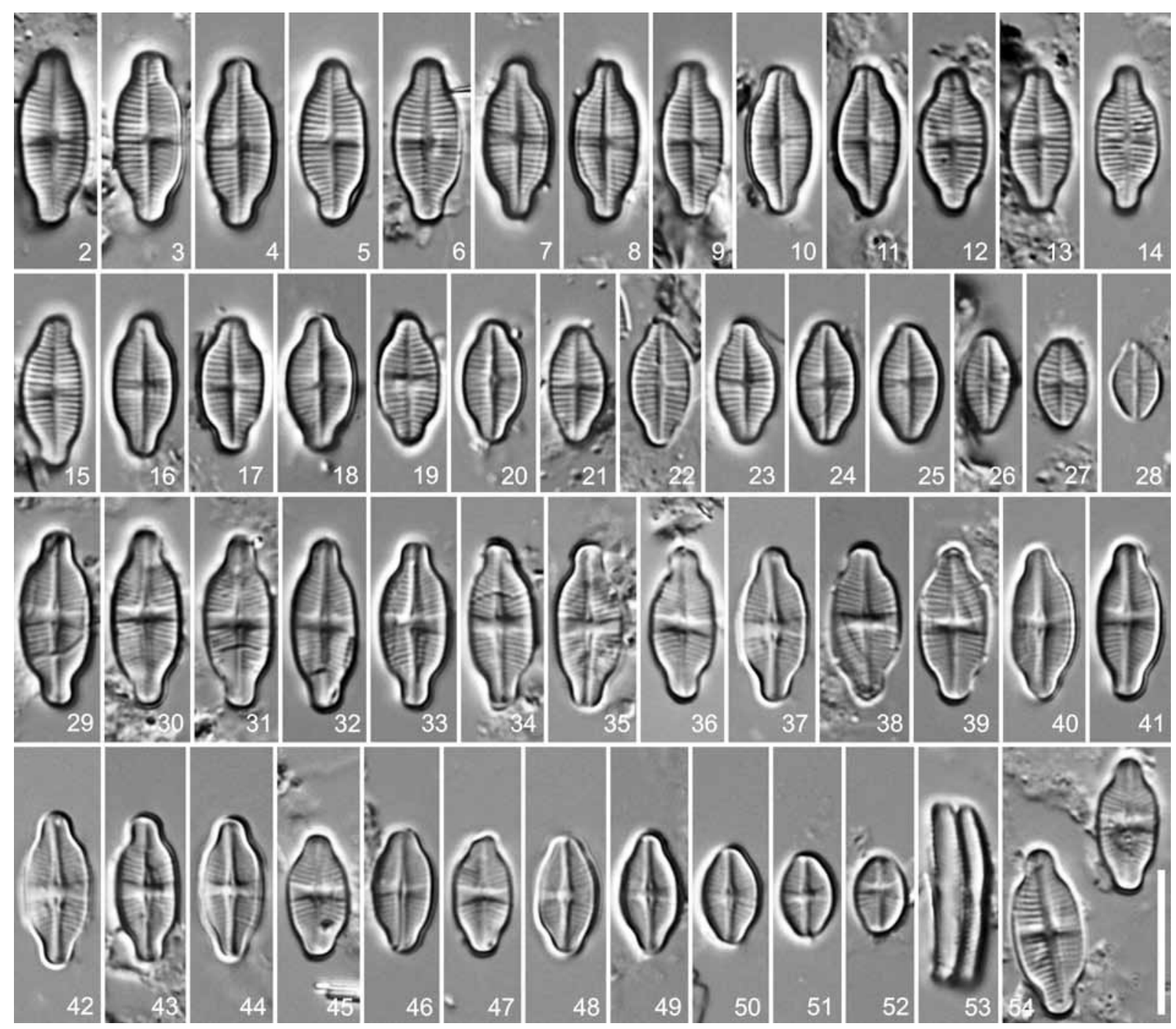

Figs 2-54. Achnanthidium exiguum. LM. Sample 397 Stauroneis exilis, stagnant water near a watermill Tacarigua XVI No 42. (2-28) rapheless valve views; (29-52) raphe valve views; (53) girdle view; (54) rapheless and raphe valve view. Scale bar $10 \mu \mathrm{m}$.

microscopy (SEM), aliquots of the oxidized suspensions were filtered through $1 \mu \mathrm{m}$ pore size polycarbonate filters that were cut into small pieces and fixed on aluminum stubs after air-drying. The stubs were sputter-coated with $50 \mathrm{~nm}$ of $\mathrm{Au}$ and examined at the Natural History Museum (London, UK) using a Zeiss Ultra plus SEM at $8 \mathrm{kV}$. Micrographs were digitally manipulated and plates containing light and scanning electron microscopy images were created using Adobe Photoshop 4.0 ${ }^{\circledR}$. Diatom terminology follows Ross et al. (1979), Round et al. (1990) and BuKhtIYARova \& Round (1996).

\section{Results}

Achnanthidium exiguum (Grunow) CZarnecki 1994 (Figs 2-64)

Basionym: Achnanthes exigua Grunow in Cleve \& Grunow 1880, p. 21.; Replaced synonym: Stauroneis exilis KüTzING 1844, p. 105, fig. 30: 21.

Light microscopy (Figs 2-54): Frustules in girdle view narrow, rectangular forming short chains, weakly curved (Fig. 53). Valves narrowly lanceolate with clearly convex margins and protracted, short rostrate, broadly rounded apices. Smaller specimens almost elliptical lacking protracted apices (Figs 28, 51, 52). Shoulders poorly developed. Valve dimensions $(n=125)$ : length 5.1-12.3 $\mu \mathrm{m}$, width $3.3-5.1 \mu \mathrm{m}$. Axial area very narrow, linear, opening rather abruptly to the central area. Rapheless valve: central area asymmetrical, on one side forming a hyaline area up to the valve margin, on the other side formed by weakly more distant striae; striae almost parallel becoming more radiate towards the apices, 24-30 in $10 \mu \mathrm{m}$. Raphe valve: central area forming a more or less symmetrical narrow, rectangular to wedge-shaped fascia reaching the valve margins; no shortened striae present in the central area; striae radiate throughout, more strongly radiate near the apices, 27-31 in $10 \mu \mathrm{m}$. Raphe branches straight with straight, clearly expanded proximal raphe endings. Distal raphe fissures indistinct in LM. Areolae not discernible in LM. 

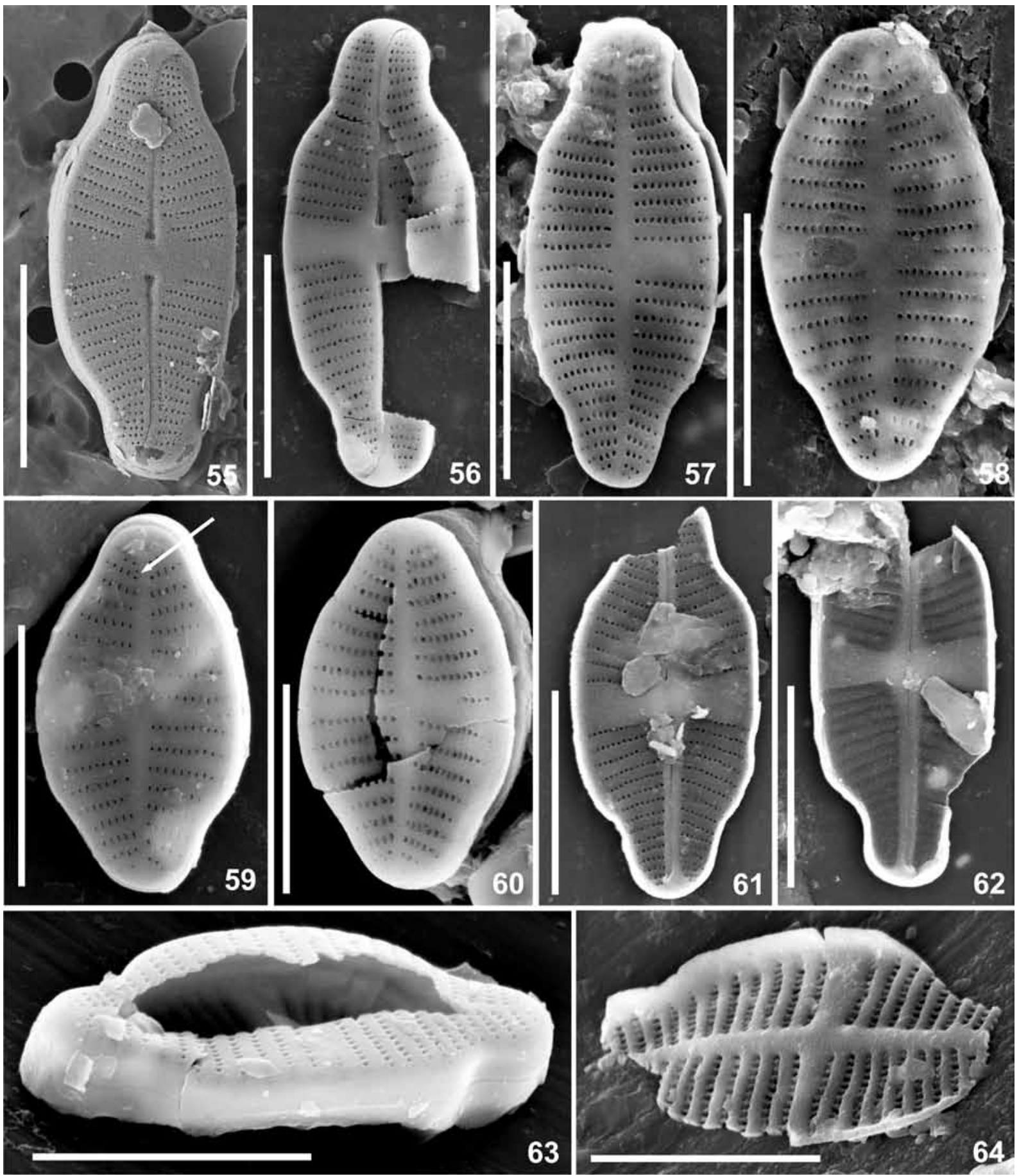

Figs 55-64. Achnanthidium exiguum. SEM. Sample 397 Stauroneis exilis, stagnant water near a watermill Tacarigua XVI No 42. (55-56) raphe valve, entire view of the valve exterior; (57-60) Rapheless valve, entire view of the valve exterior. The arrow in Fig. 59 indicates the biseriate part of the striae. (61-62) raphe valve, entire view of the valve interior; (63) girdle view; broken rapheless valve situated on top; (64) rapheless valve, partial view of the valve interior. Note the raised virgae. Scale bar $5 \mu \mathrm{m}(55-59,61-63), 4 \mu \mathrm{m}(60,64)$.

Scanning electron microscopy (Figs 55-64): Striae of the raphe valve narrower than the virgae, uniseriate composed of very small, usually rounded areolae (Figs $55,56)$. Proximal raphe endings straight, clearly expanded, forming a groove around the raphe (Fig. 56). Distal raphe fissures deflected to opposite sides (Fig. $55)$, terminating in droplike pores on the valve face (Fig. 56). Striae of the rapheless valve uniseriate, com- posed of apically elongated to rounded areolae (Figs $57-60,63)$. Near the apices, striae very occasionally biseriate near the axial area (Fig. 59, see arrow). Internally, areolae covered by individual hymenes (Fig. 62). Central area of the raphe valve forming a thickened stauros (Figs 61, 62). Proximal raphe endings shortly deflected to opposite sides (Fig. 61). Distal raphe endings terminating on small helictoglossae (Fig. 62). 

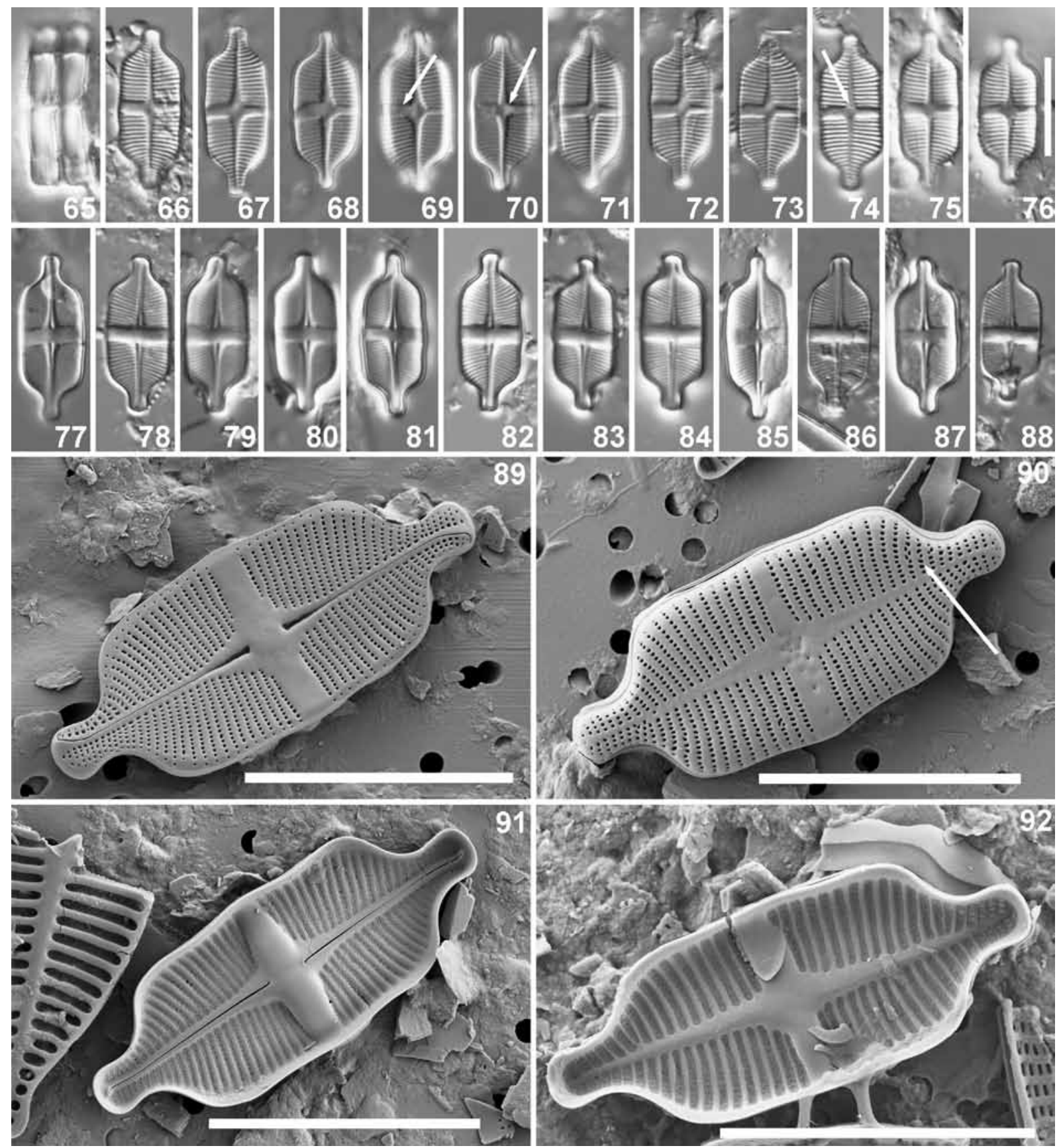

Figs 65-92. Achnanthidium australexiguum. LM and SEM. Sample D11, Monolith lake, Ulu Peninsula, James Ross Island. (65-88) LM, (65) girdle view, (66-76) rapheless valve views, (77-88) rapheless valve views; (89-92) SEM, (89) raphe valve, entire view of the valve exterior, (90) raphe valve, entire view of the valve interior, (91) rapheless valve, entire view of the valve exterior, (92) rapheless valve, entire view of the valve interior. Scale bar $10 \mu \mathrm{m}$.

Central area of the rapheless valve not or only slightly more enlarged compared to the virgae (Fig. 64).

\section{Achnanthidium australexiguUm VAN DE VIJVER sp. nov. (Figs 65-92)}

\section{Description}

Light microscopy (Figs 65-88): Frustules in girdle view narrow, rectangular forming short chains, weakly bent in the middle making the view somewhat slightly V-shaped (Fig. 65). Valves always linear with parallel, clearly undulating margins and protracted, distinctly rostrate apices. Shoulders always clearly developed. Valve dimensions $(\mathrm{n}=50)$ : length $14.7-18.8 \mu \mathrm{m}$, width 6.3-7.5 $\mu \mathrm{m}$. Populations on Livingston Island slightly larger than the type population (17.7 vs. $18.8 \mu \mathrm{m}$ ). Axial area very narrow, opening rather abruptly to the central area. Rapheless valve: central area forming a narrow, rectangular, asymmetrical fascia, lacking any shortened striae bordering the central area. Irregular markings sometimes present in the central area (Figs $69,70,74$, see arrow); striae parallel becoming radiate 
towards the apices, 23-24 in $10 \mu \mathrm{m}$. Raphe valve: central area forming a rather broad, rectangular, weakly asymmetrical fascia, lacking any shortened striae bordering the central area; striae radiate throughout, more strongly radiate near the apices, $28-30$ in $10 \mu \mathrm{m}$. Raphe branches straight with straight, clearly expanded proximal raphe endings. Distal raphe fissures deflected, almost invisible in LM. Areolae not discernible in LM.

Scanning electron microscopy (Figs 89-92): Striae of the raphe valve narrower than the virgae, uniseriate composed of very small, rounded areolae (Fig. 89). Areolae becoming larger towards the valve margins. Proximal raphe endings clearly expanded, forming a groove around the raphe (Fig. 89). Distal raphe fissures deflected to opposite sides, terminating in droplike pores on the valve face (Fig. 89). Striae of the rapheless valve uniseriate, composed of apically elongated to rounded areolae (Fig. 90). Near the apices, striae occasionally biseriate (Fig. 90, see arrow). Shallow depressions sometimes present in the central area (Fig. 90). Internally, areolae covered by cribrate structures (Figs 91, 92). Central area on both valves forming a thickened stauros, more developed in the raphe valve than in the rapheless valve (Figs 91, 92). Proximal raphe endings shortly deflected to opposite sides (Fig. 91). Distal raphe endings straight and terminating on small helictoglossae (Fig. 91).

Holotype (designated here): BR-4347 (National Botanic Garden, Meise, Belgium)

Isotypes (designated here): PLP-241 (University of Antwerp, Belgium), BRM-ZU9/43 (Hustedt Collection, Bremerhaven, Germany)

Type locality: Monolith Lake, Ulu Peninsula, James Ross Island, sample JRI-D11 (Coll. L. NedBalovÁ and J. Elster) (01/02/2008).

Etymology: The specific epithet refers to the close resemblance to Achnanthidium exiguum and its geographic distribution in the southern hemisphere ('australis').

Ecology and Distribution: At present, confirmed records of this new taxon exist from James Ross Island (this study), Livingston Island (this study), King George Island (YANG \& CHEN 1994, based on analysis of their illustrations) and Beak Island (STERKEN et al., unpubl. data). It is likely that the species is more widely distributed in the Maritime Antarctic Region as literature data reported $A$. exiguum from Horseshoe Island (WASEll \& HÅKansson 1992) and the South Orkney Islands (HÅKANSSON \& JONES 1994) but as illustrations are lacking in these publications, an unambiguous identification is not possible at the moment.

The largest population of Achnanthidium australexiguum was observed in the epipelon and epilithon of Monolith Lake on James Ross Island, a large lake with circumneutral $\mathrm{pH}$ (7.24), a low specific conductance $\left(120 \mu \mathrm{S} . \mathrm{cm}^{-1}\right)$ and low values of total phosphorus $(9.7$ $\left.\mu \mathrm{g} . \mathrm{l}^{-1}\right)$ and sulphate $\left(14 \mu \mathrm{g} . \mathrm{l}^{-1}\right)$. The diatom flora in this lake was dominated by Nitzschia cf. perminuta (GRUnow) Peragallo, Navicula cremeri Van de ViJVer et Zidarova, Diadesmis australis VAN DE VIJVER et SABBE and Fragilaria capucina s.1. DesMAZIÈRES. Other (but smaller) populations were found in weakly alkaline lakes ( $\mathrm{pH} 7.6-7.7)$ with low specific conductance values $\left(110-190 \mu \mathrm{S} . \mathrm{cm}^{-1}\right)$.

\section{Discussion}

The type material of Achnanthes exigua shows some features that separate this taxon from the genus Achnanthidium. Based on the emended description given by Round \& BukhtiYarova (1996), the genus is characterized in having cells with a valves less than 30 $\mu \mathrm{m}$ long and $5 \mu \mathrm{m}$ wide, concave raphe and convex rapheless valves and distal raphe fissures that are either straight or curved to one side. Achnanthes exigua has slightly wider valves $(3.3-5.1 \mu \mathrm{m})$, although still within the range for the genus Achnanthidium. However, the distal raphe fissures are curved into opposite directions. CzARneCKi (1994) transferred A. exigua to Achnanthidium but did not justify this new combination. The presence of the distal raphe endings curved into opposite directions is unique within the genus Achnanthidium. Potapova \& Ponader (2004) discuss several Achnanthidium species with unilaterally curved distal raphe endings but do not refer to taxa with raphes curved in opposite directions. Moser et al. (1995, 1998) reported on four Achnanthes taxa from New Caledonia with a short sigmoid raphe, later transferred by LANGe-Bertalot (1999) to the genus Achnanthidium. Within the monoraphid diatom genera, two other genera present taxa with curved raphe endings. All species in the genus Eucocconeis Cleve have a typical sigmoid raphe with distal fissures curved to opposite directions (Round et al. 1990) and within the genus Psammothidium, several species are known with a similar sigmoid raphe such as $P$. germainii (MAnguin) SABbe (SABbe et al. 2003). Both genera however present sufficient morphological differences with $A$. exiguum to justify a transfer to either of these two genera. Nevertheless, it is clear that in the present concept of Achnanthidium, the taxa with the sigmoid raphe represent a separate entity. At present however, a transfer of these Achnanthidium taxa to a new genus solely based on the structure of their raphe seems too premature and should ideally be supported by molecular or cladistic data. Therefore, the new Antarctic species, showing a similar sigmoid raphe is described in the genus Achnanthidium.

After a careful analysis of the type material, it is clear that the Maritime Antarctic populations of Achnanthidium exiguum are not conspecific with the type material, justifying the separation of the former populations 
as a new taxon. Achnanthidium exiguum shows rather narrow, elliptic-lanceolate valves with short, broadly rounded rostrate apices, contrary to the larger, strictly linear valves with longer, rostrate apices. The shoulders seem less developed in $A$. exiguum contrary to $A$. australexiguum. Apart from additional clear differences in the morphometric data (with A. australexiguum being much larger than $A$. exiguum, 14.7-18.8 $\mu \mathrm{m}$ and 5.1-12.3 $\mu \mathrm{m}$ respectively), the biggest difference however is the presence of a clear, well-developed stauros in the rapheless valves of $A$. australexiguum whereas in $A$. exiguum, the valves only show an asymmetrical widening of the central area on one side of the valve whereas on the other side, the striae are only very faintly more spaced. In several cases, one complete stria is present in the central area on one side. In all cases, shallow pit-like depressions, as often seen in the central area of $A$. australexiguum were lacking in A. exiguum. The proximal raphe endings are more expanded and larger in A. australexiguum although both taxa seem to possess a certain groove around the proximal raphe ending. The axial area widens more clearly into the central area in A. australexiguum contrary to $A$. exiguum where no widening of the axial area was observed. Based on these differences, a separation of both taxa can be justified.

Our observations of the type of A. exiguum will hopefully also lead to a better understanding of the true identity of $A$. exiguum. Inevitably, using a more refined species concept, it will lead to a multiplicity of new taxa that need to be described, taxa that were formerly all included within Achnanthes exigua s.l. The taxon shown in Schoeman \& Archibald (1976) for instance has a rapheless valve bearing a complete, though asymmetrical stauros and probably represents a separate taxon (see Schoeman \& Archibald 1976, figs 2-10). In the past, A. exiguum was considered as being a highly variable taxon resulting in the description of a large number of infraspecific taxa (varieties and forms) (FourTANiER \& KocIOLEK 2011). Several of these forms and varieties of $A$. exiguum show some similarities with the new taxon but present sufficient differences to separate them from $A$. australexiguum. The most similar one to A. australexiguum is Achnanthes exigua var. angustirostrata (KRASSKE) LANGE-BERTALOT, described from southern Chile in 1939. The latter shows the presence of a similar complete fascia in both rapheless and raphe valve although in the original line drawing of the rapheless valve that accompanied the description (KRASSKE 1939, fig. 11: 6) this was not visible. However, Lange-Bertalot et al. (1996) clearly show the presence of the fascia on the rapheless valve. Differences between both taxa include a higher stria density (ca 33 vs. $28-30$ in $10 \mu \mathrm{m}$ ) on the raphe valve and more acutely shaped, rostrate apices compared to the broad rostrate apices in A. australexiguum.

ToRkA (1909) described $A$. exigua var. constricta (ToRka) Hustedt [originally described from Poznan
(Posen) as Cocconeis, in 1930 transferred by HustedT to the genus Achnanthes] showing a similar complete fascia but with a clear constriction in the middle giving the taxon a well-developed undulating valve outline which is lacking in all investigated populations of $A$. australexiguum. Moreover, the apices are much broader in the former variety than in the new taxon.

In 1934, CLEVE-EulER described Achnanthes rostellata Cleve-Euler but this taxon can be separated by its rapheless valve lacking a fascia in its central area and by a very narrow fascia on the raphe valve, contrary to A. australexiguum where a clear fascia is found on both valves.

So far, A. australexiguum has only been found in the Maritime Antarctic Region. Careful analysis of samples from both the sub-Antarctic Region and the Antarctic Continent did not reveal any presence of this species in these regions (VAN DE VIJVER, pers. obs.). Literature data from the sub-Antarctic Region reporting on the monoraphid diatom flora never mentioned the presence of Achnanthidium exiguum, Achnanthes exigua, Stauroneis exilis or later synonyms (LE COHU \& Maillard 1983; Le Cohu 2005; Van de ViJver et al. 2002). This restricted distribution confirms once more the unique character of the diatom flora of the Maritime Antarctic Region that has been demonstrated in several other genera such as Muelleria (VAN DE VIJVER et al. 2010), Hantzschia (Zidarova et al. 2010), Luticola (KopalovÁ et al. 2011) and Navicula (VAN DE VIJVER et al. 2011).

ACKnowledgements

Samples on Byers Peninsula were taken in the framework of the IPY-Limnopolar Project POL2006-06635 (Ministerio de Ciencia y Tecnología, Spain). The authors would also like to thank the members of expeditions to the Czech J.G. Mendel Antarctic Station for their support and help in the field. Part of the research was funded within the BELSPO project CCAMBIO and an EU Synthesys grant to BVDV to visit the National History Museum in London, UK. Alex Ball, the staff of the EMMA laboratory and Eileen J. Cox at the Natural History Museum are thanked for their help with the scanning electron microscopy. J. C. TAYLOR is the recipient of South African National Research Foundation (NRF) incentive funding. Any opinions, findings and conclusions or recommendations expressed in this material are those of the author(s) and therefore the NRF does not accept any liability in regard thereto. J. C. TAYLOR is a beneficiary of a mobility grant from the Marie Curie Actions of the European commission co-financed by the Belgian Federal Science Policy.

\section{REFERENCES}

Alakananda, B.; Mahesh, M.K. \& Ramachandra, T.V. (2013): Role of environmental variables in diatom distribution in urban wetlands of Peninsular India. Diatom 29: 1-11.

Bukhtiyarova, L. \& Round, F.E. (1996): Revision of the genus Achnanthes sensu lato. Psammothidium, a new genus based on A. marginulatum. - Diatom Research 11: $1-30$. 
Cleve, P.T. \& Grunow, A. (1880): Beiträge zur Kenntniss der arctischen Diatomeen. - Kongliga Svenska Vetenskaps-Akademiens Handlingar 17: 1-121.

Cleve-Euler, A. (1934): The Diatoms of Finnish Lapland. - Societas Scientiarum Fennica. Commentationes Biologicae 4: 1-154.

Cleve-Euler, A. (1953): Die Diatomeen von Schweden und Finnland. Teil III Monoraphideae, Biraphideae 1. Kunglica Svenska Vetenskaps-Akademiens Handlingar, Serie 4 5/4: 1-255.

Czarnecki, D.B. (1994): The freshwater diatom culture collection at Loras College, Dubuque, Iowa. - In: KocioleK, J.P. (ed.): Proceedings of the 11th International Diatom Symposium, San Francisco, 12-17 August 1990. Memoirs of the California Academy of Sciences 17: 155-174.

Ehrenberg, C.G. (1843) Verbreitung und Einflufs des mikroskopischen Lebens in Süd-und Nord-Amerika. - Abhandlungen der Königlichen Akademie der Wissenschaften zu Berlin 1841: 291-445.

Fourtanier, E. \& KocioleK, J.P. (2011): Catalogue of Diatom Names, California Academy of Sciences, On-line Version updated 19 Sept. 2011. - Available online at http://research.calacademy.org/research/diatoms/ names/index.asp

HÅkansson, H. \& Jones, V.J. (1994): The compiled freshwater diatom taxa list for the maritime region of the South Shetland and South Orkney Islands. - In: HAMILTON, P.B. (ed.): Proceedings of the Fourth ArcticAntarctic Diatom Symposium Workshop, Canadian Technical report of Fisheries and Aquatic Sciences 157: 77-83.

Hustedt, F. (1930): Bacillariophyta (Diatomeae). - In: PASCHER, A. (ed.): Die Süsswasser-Flora Mitteleuropas. Zweite Auflage. Heft 10. - 466 pp., 875 figs, Gustav Fischer, Jena.

Hustedt, F. (1937): Systematische und ökologische Untersuchungen über die Diatomeen-Flora von Java, Bali und Sumatra nach dem Material der Deutschen Limnologischen Sunda-Expedition. „Tropische Binnengewässer, Band VII“. - Archiv für Hydrobiologie, Supplement 15: 393-506.

KellogG, T.B. \& KellogG, D.E. (2002): Non-marine and littoral diatoms from Antarctic and subantarctic regions. Distribution and updated taxonomy. - Diatom Monographs 1: 1-795.

Kopalová, K. \& Van de Vijver, B. (2013): Structure and ecology of freshwater diatom communities of Byers Peninsula (Livingston Island, South Shetland Islands). - Antarctic Science 25: 239-253.

Kopalová, K.; Nedbalová, L.; de Haan, M. \& Van de ViJVER, B. (2011): Description of five new species of the diatom genus Luticola (Bacillariophyta, Diadesmidaceae) found in lakes of James Ross Island (Maritime Antarctic Region). - Phytotaxa 27: 44-60.

Kopalová, K.; NedbalovÁ, L.; NÝvlt, D.; Elster, J. \& Van DE VIJVER, B. (2013): Ecological assessment of the freshwater diatom communities from Ulu Peninsula (James Ross Island, NE Antarctic Peninsula). - Polar Biology 36: 933-948.

KrassKe, G. (1939): Zur Kieselalgenflora Südchiles. - Archiv für Hydrobiologie und Planktonkunde, Stuttgart 35: 349-468.

KüTZING, F.T. (1833): Synopsis Diatomacearum oder Versuch einer systematischen Zusammenstellung der Diato- meen. - Linnaea 8: 529-620.

KütZING, F.T. (1844): Die Kieselschaligen. Bacillarien oder Diatomeen. - 152 pp., Nordhausen.

Lange-Bertalot, H. \& Krammer, K. (1989): Achnanthes, eine Monographie der Gattung mit definition der Gattung Cocconeis und Nachträgen zu den Naviculaceae. - Bibliotheca Diatomologica 18: 1-393.

Lange-Bertalot, H.; Külbs, K.; Lauser, T.; NörpelSchempr, M. \& Willmann, M. (1996): Dokumentation und Revision der von Georg KRASSKE beschriebenen Diatomeen-Taxa. - Iconographia Diatomologica 3: 1-358.

Lange-Bertalot, H. (1999): Neue Kombinationen von Taxa aus Achnanthes BORY (sensu lato). - Iconographia Diatomologica 6: 276-289.

Le CoHu, R. \& MaILlard, R. (1983): Les diatomées monoraphidées des îles Kerguelen. - Annales de Limnologie 19: $143-167$.

LE CoHU, R. (2005): Revision of the main freshwater species of Achnanthales (Bacillariophyta) from sub-antarctic Iles Kerguelen. - Algological Studies 116: 79-114.

Metzeltin, D.; Lange-Bertalot, H. \& García-Rodríguez, F. (2005): Diatoms of Uruguay, compared with other taxa from South America and elsewhere. - Iconographia Diatomologica 15: 1-736.

Moser, G.; Steindorf, A. \& Lange-Bertalot, H. (1995): Neukaledonien Diatomeenflora einer Tropeninsel. Revision der collection Maillard und Untersuchung neuen materials. - Bibliotheca Diatomologica 32: 1-340.

Moser, G.; Lange-Bertalot, H. \& Metzeltin, D. (1998): Insel der Endemiten Geobotanisches Phänomen Neukaledonien (Island of endemics New Caledonia - a geobotanical phenomenon). - Bibliotheca Diatomologica 38: 1-464.

Potapova, M. G. \& Ponader, K. C. (2004): Two common North American diatoms, Achnanthidium rivulare sp. nov. and A. deflexum (Reimer) Kingston: morphology, ecology and comparison with related species. Diatom Research 19: 33-57.

Reichardt, E. (1995): Die Diatomeen (Bacillariophyceae) in EhrenBergs Material von Cayenne, Guyana Gallica (1843). - Iconographia Diatomologica 1: 1-99.

Ross, R.; Cox, E.J.; KaraYeva, N.I.; ManN, D.G.; Paddock, T.B.B.; SimONSEN, R. \& Sims, P.A. (1979): An amended terminology for the siliceous components of the diatom cell. - Nova Hedwigia Beiheft 64: 513-533.

Round, F.E. \& Bukhtiyarova, L. (1996): Four new genera based on Achnanthes (Achnanthidium) together with a re-definition of Achnanthidium. - Diatom Research 11: 345-361.

Round, F.E.; Crawford, R.M. \& Mann, D.G. (1990): The diatoms. Biology and morphology of the genera. -747 pp., Cambridge University Press, Cambridge.

Sabbe, K.; Verleyen, E.; Hodgson, D.A.; Vanhoutte, K. \& VYVERMAN, W. (2003): Benthic diatom flora of freshwater and saline lakes in the Larsemann Hills and Rauer Islands, East-Antarctica. - Antarctic Science 15: 227-248.

Schoeman, F.R. \& Archibald, R.E.M. (1976): The diatom flora of South Africa. Part 3. C.S.I.R. Special Reports, Pretoria.

Torka, V. (1909): Diatomeen einiger Seen der Provinz Posen. - Zeitschrift der Naturwissenschaften Abteilung der deutschen Gesellschaft fuer Kunst und Wissenschaft in Posen 16: 1-11. 
Trobajo, R.; Clavero, E.; Chepurnov, V.A.; Sabbe, K., ManN, D.G.; Ishihara, S. \& Cox, E.J. (2009): Morphological, genetic and mating diversity within the widespread bioindicator Nitzschia palea (Bacillariophyceae). - Phycologia 48: 443-459.

Trobajo, R.; Rovira, L.; Ector, L.; Wetzel, C.E.; Kelly, M. \& MANN, D.G. (2013): Morphology and identity of some ecologically important small Nitzschia species. - Diatom Research 28: 37-59.

TYLER, P.A. (1996): Endemism in freshwater algae. - Hydrobiologia 336: 127-135.

Van de Vijver, B.; Frenot, Y. \& Beyens, L. (2002): Freshwater diatoms from Ile de la Possession (Crozet Archipelago, Subantarctica). - Bibliotheca Diatomologica 46: 1-412.

Van de Vijver, B.; Mataloni, G.; Stanish, L. \& Spaulding, S.A. (2010): New and interesting species of the genus Muelleria (Bacillariophyta) from the Antarctic Region and South Africa. - Phycologia 49: 22-41.

Van de Vijver, B.; Zidarova, R.; Sterken, M.; Verleyen, E.; de Haan, M.; Vyverman, W.; Hinz, F. \& Sabbe, K. (2011): Revision of the genus Navicula s.s. (Bacillariophyceae) in inland waters of the Sub-Antarctic and Antarctic with the description of five new species. - Phycologia 50: 281-297.

Van de Vijver, B.; Wetzel, C.E.; Kopalová, K.; Zidarova, R. \& Ector, L. (2013): Analysis of the type material of Achnanthidium lanceolatum BrÉBISSON ex
KützING (Bacillariophyta) with the description of two new Planothidium species from the Antarctic Region. - Fottea 13: 105-117.

VAN DER WERFF, A. (1955): A new method for cleaning and concentrating diatoms and other organisms. - Verhandlungen der Internationalen Vereinigung für theoretische und angewandte Limnologie 12: 276-277.

Van Heurck, H. (1880-1885): Synopsis des Diatomées de Belgique. - 235pp., Anvers, Belgium.

Wasell, A. \& HÅkansson, H. (1992): Diatom stratigraphy in a lake on Horseshoe Island, Antarctica: a marinebrackish-freshwater transition with comments on the systematics and ecology of the most common diatoms. - Diatom Research 7: 157-194.

Wetzel, C.E.; Morales, E.A.; Hinz, F.; De Bicudo, D. \& EcTOR, L. (2013): Fragilariforma javanica comb. nov.: analysis of type material of a widely reported species with a tropical distribution. - Diatom Research 28: 373-379.

YANG, S. \& CHEN, X. (1994): Late Quaternary diatoms from the Yan'ou Lake, King George Island, Antarctica (III). Diatomales, Achnanthales and Surirellales. Acta Micropaleontologica Sinica 11: 303-318.

Zidarova, R.; Van de Vijver, B.; Quesada, A. \& de Haan, M. (2010): Revision of the genus Hantzschia (Bacillariophyceae) on Livingston Island (South Shetland Islands, Southern Atlantic Ocean). - Plant Ecology \& Evolution 143: 318-333.

(C) Czech Phycological Society (2014)

Received September 21, 2013

Accepted December 16, 2013 